\title{
PENGARUH PERSENTASE REDUKSI WARM ROLLING TERHADAP SIFAT MEKANIK PADUAN Cu-Zn 70/30
}

\section{PERCENTAGE OF WARM ROLLING REDUCTION EFFECT ON MECHANICAL PROPERTIES OF CU-Zn 70/30 ALLOY}

\author{
Ayu Rizeki Ridhowati ${ }^{1, a}$, Eka Febriyanti ${ }^{2, b}$, Rini Riastuti ${ }^{2, c}$ \\ ${ }^{1}$ Departemen Teknik Metalurgi dan Material, Fakultas Teknik, Universitas Indonesia, Depok, \\ Indonesia \\ ${ }^{2}$ Balai Besar Teknologi Kekuatan Struktur (B2TKS), Badan Pengkajian dan Penerapan \\ Teknologi (BPPT), PUSPIPTEK, Serpong, 16314, Indonesia \\ e-mail: ${ }^{b}$ eka.febriyanti@bppt.go.id, ${ }^{c}$ rini.riastuti@yahoo.com
}

\begin{abstract}
Abstrak
Warm rolling merupakan salah satu metode termomekanik yang mempunyai beberapa keuntungan yaitu salah satunya menghasilkan sifat mekanik yang tinggi, namun tidak mengurunkan nilai keuletan karena adanya fenomena rekristalisasi parsial yang menghasilkan butiran baru berbentuk micron. Paper ini menjelaskan tentang hasil penelitian berupa pengaruh persentase reduksi terhadap sifat mekanis paduan $\mathrm{Cu}-\mathrm{Zn}$ 70/30. Paduan Cu-Zn 70/30 setelah dilakukan proses homogenisasi dan didinginkan di udara lalu dipanaskan ke suhu $300^{\circ} \mathrm{C}$, kemudian masing-masing dilakukan warm rolling dengan persentase reduksi sebesar $25 \%$, 30\%, dan 35\% kemudian ditahan di suhu $300^{\circ} \mathrm{C}$ dalam waktu 120 menit. Selanjutnya sampel dilakukan rewarm rolling dengan persentase reduksi sebesar $25 \%$, 30\%, dan 35\%. Hasil penelitian yang dilakukan antara lain nilai kekuatan tarik (UTS dan YS) yang semakin tinggi sebanding dengan peningkatan $\%$ reduksi warm rolling yaitu masing-masing untuk nilai UTS sebesar 501,1 MPa; 599,3 MPa; lalu menurun menjadi 546,5 MPa serta untuk nilai kekuatan luluh sebesar 441,8 MPa; 466,1 MPa; lalu menurun menjadi 458,6 MPa. Selain itu, nilai kekerasan meningkat sebanding dengan peningkatan \% reduksi warm rolling masing-masing sebesar 154 HV; 162 HV; lalu menurun menjadi 160 HV. Sedangkan persentase elongasi semakin menurun berbanding terbalik dengan peningkatan \% reduksi masing-masing sebesar 12,4\%; 8,2\%; lalu meningkat menjadi 11,2\%. Hal tersebut disebabkan karena adanya fenomena rekristalisasi parsial yang dibuktikan dengan kehadiran butir kecil berukuran mikron.
\end{abstract}

Kata kunci : Paduan Cu-Zn 70/30, warm rolling, anil, \% reduksi, sifat mekanik

\begin{abstract}
Warm rolling is one of the thermomechanical method has several advantages such as produces high mechanical properties, but does not decrease \% elongation and toughness value because partial recrystallization phenomenon that produces micron-sized new grain. This paper reports the results of an investigation carried out on the effects of holding time annealing to mechanical properties $\mathrm{Cu}-\mathrm{Zn} 70 / 30$ alloy. These alloy after homogenization process and quenched in the air then heated to temperature of $300^{\circ} \mathrm{C}$, later the heated copper samples are warm rolled at $25 \%, 30 \%$, and $35 \%$ reduction, after that heated at temperature $300^{\circ} \mathrm{C}$ and held during 120 minutes. Then sample is experienced rewarm rolling with reduction $25 \%, 30 \%$, and $35 \%$. The results obtained showed that the ultimate tensile strength and yield strength are higher proportional with the increasing of \% reduction, their values are 501,1 MPa; 599,3 MPa; later decrease to 546, $5 \mathrm{MPa}$ and to yield strength are 441,8 MPa; 466,1 MPa; then decrease to 458,6 MPa. Moreover hardness value increase proportional with \% reduction such as $154 \mathrm{HV} ; 162 \mathrm{HV}$; after that decrease to $160 \mathrm{HV}$ While, \% elongation decreases inversely proportional with \% reduction namely $12,4 \%$; $8,2 \%$; later increase to $11,2 \%$. It is caused of the partial recrystallization phenomenon as evidenced by the presence micron-sized.
\end{abstract}

Key word : Cu-Zn 70/30 alloy, warm rolling, anneal, \% reduction, mechanical properties

\section{PENDAHULUAN}

Deformasi logam pada suhu ruang diakomodasi oleh lapisan atom-atom yang bergeser dari satu butiran kristal ke butiran kristal lainnya pada logam. Ketika pergese- ran terjadi, butiran logam menjadi terdistorsi, lapisan-lapisan atom saling berkait, dan ada peningkatan tegangan pada daerah kecil di dislokasi atom dalam butir ${ }^{(1)}$. Oleh karena distorsi dan peningkatan kerapatan dislokasi menyebabkan dislokasi sangat sulit untuk 
bergerak melewati kumpulan dislokasi lainnya yang menyebabkan logam berdeformasi sehingga meningkatkan regangan dan cold hardening. Apabila deformasi atau cold working ini terus berlanjut, logam ulet seperti tembaga akan menjadi getas selama deformasi ${ }^{(2)}$.

Sedangkan menurut Kouzeli dan Mortensen $^{(3)}$, ukuran dari mikrostruktur material dapat memberikan pengaruh kuat terhadap sifat mekanik yang disebabkan adanya pembatas terhadap mekanisme deformasi tertentu. Dislokasi kisi didorong oleh batasan mikrostruktur untuk mundur (bow out) atau bertumpuk sehingga pergerakannya membutuhkan tegangan eksternal tergantung dari parameter mikrostruktur ${ }^{(4)}$. Tembaga mempunyai konduktivitas yang tinggi, namun memiliki ketahanan terhadap pelunakan pada suhu tinggi ${ }^{(5)}$. Hal ini menjadi masalah bagi enjiner dan desainer peralatan listrik. Salah satu mekanisme yang digunakan untuk meningkatkan sifat mekanik dari tembaga adalah dengan anneal hardening, dimana mekanisme pengerasan yang lebih besar terjadi ketika paduan tembaga dalam kondisi canai dingin lalu dilakukan perlakuan panas $^{(6)}$.

Pada penelitian oleh Eka Febriyanti ${ }^{(7)}$, dilakukan TMCP (Thermo Mechanical Controlled Process) pada suhu pengerjaan hangat $300^{\circ} \mathrm{C}$, dengan media pendingin udara dan metode canai bolak-balik sebanyak dua kali pass. Dari penelitian tersebut disimpulkan bahwa semakin besar persentase reduksi, maka butir semakin halus. Selain itu, nilai kekerasan dan ultimate tensile strength serta yield strength cenderung menunjukkan peningkatan. Hasil penelitian tersebut memang sesuai dengan metode penghalusan butir menggunakan parameter Hall-Petch, namun persentase reduksi tidak sesuai dengan teoritis akibat adanya mekanisme strain hardening. Berdasarkan hal tersebut, perlu dipelajari lebih dalam mekanisme penghalusan butir melalui proses warm rolling dengan pengontrolan suhu pemanasan sebelum benda diberikan pengerjaan warm rolling.

Untuk meningkatkan persentase reduksi efek pengerasan akibat pemanasan (anneal hardening) perlu diminimalisasi.
Anneal hardening biasanya terjadi karena paduan $\mathrm{Cu}-\mathrm{Zn}$ 70/30 dalam kondisi dingin dilakukan perlakuan panas pada suhu $300^{\circ} \mathrm{C}^{[6,7)}$. Anneal hardening effect biasanya terjadi dalam rentang suhu $152-300^{\circ} \mathrm{C}$ selama $120 \mathrm{~s} / \mathrm{d} 240$ menit $^{(8)}$. Oleh karena itu, paduan $\mathrm{Cu}-\mathrm{Zn} 70 / 30$ perlu diberi perlakuan panas selama minimal 120 menit sebelum melakukan proses canai untuk pass selanjutnya yang bertujuan untuk menghilangkan efek anneal hardening.

Penelitian ini dilakukan untuk mempelajari pengontrolan suhu ketika TMCP pada paduan Cu-Zn (70/30) setelah dilakukan proses pemanasan selama 120 menit sebelum pass kedua ketika warm rolling dengan metode double pass reversible pada suhu $300^{\circ} \mathrm{C}$ serta pengaruhnya terhadap sifat mekanik material paduan $\mathrm{Cu}-\mathrm{Zn}$ 70/30 tersebut.

\section{PROSEDUR PERCOBAAN}

Benda uji yang digunakan adalah paduan $\mathrm{Cu}-\mathrm{Zn}$ 70/30 dengan hasil komposisi yang terlihat pada Tabel 1.

Tabel 1. Komposisi benda uji paduan Cu-Zn $70 / 30$

\begin{tabular}{|c|c|c|}
\hline Unsur & $\begin{array}{c}\text { Penelitian } \\
\text { (\% berat) }\end{array}$ & $\begin{array}{c}\text { Spesifikasi } \\
\text { ASTM B36M- } \\
13^{[9]}(\% \\
\text { berat })\end{array}$ \\
\hline $\mathrm{Cu}$ & 69,5 & $69.5-72$ \\
\hline $\mathrm{Zn}$ & 30,7 & sisa \\
\hline $\mathrm{Fe}$ & 0,026 & Maks. 0,05 \\
\hline $\mathrm{Sn}$ & 0,0062 & Maks. 0,03 \\
\hline $\mathrm{Al}$ & $<0,002$ & Maks. 0,03 \\
\hline $\mathrm{Ni}$ & - & Maks. 0,2 \\
\hline $\mathrm{As}$ & $<0,001$ & Maks. 0,02 \\
\hline $\mathrm{Pb}$ & $<0,005$ & Maks. 0,05 \\
\hline $\mathrm{Si}$ & $<0,005$ & Maks. 0,01 \\
\hline $\mathrm{Mn}$ & 0,0052 & Maks. 0,04 \\
\hline $\mathrm{P}$ & $<0,003$ & Maks. 0,05 \\
\hline $\mathrm{Sb}$ & - & Maks. 0,01 \\
\hline $\mathrm{Bi}$ & - & Maks. 0,04 \\
\hline
\end{tabular}

Pengujian komposisi material paduan $\mathrm{Cu}-\mathrm{Zn}$ 70/30 dilakukan dengan menggunakan Optical Emission Spectroscopy (OES) di laboratorium.

Ukuran benda uji yang digunakan dalam penelitian ini adalah pelat berdimensi $100 \mathrm{~mm} \times 100 \mathrm{~mm} \times 3,1 \mathrm{~mm}$. Lalu pada salah satu ujung benda uji dibor untuk 
membuat lubang sebesar $2,5 \mathrm{~mm}$ yang digunakan sebagai penjepit kawat termokopel. Kawat termokopel berfungsi sebagai alat untuk mengukur suhu. Kawat termokopel tipe $\mathrm{K}$ yang dimasukkan ke lubang harus terjepit dengan baik karena pada saat rolling, kawat juga akan ikut terdeformasi. Jika penjepitan kurang sempurna, maka kawat akan terlepas dan data suhu pada proses rolling tidak dapat terekam/dimonitor.

Pengukuran suhu menggunakan data acquisition system yang dihubungkan dengan perangkat komputer seperti yang ditampilkan pada Gambar 1.

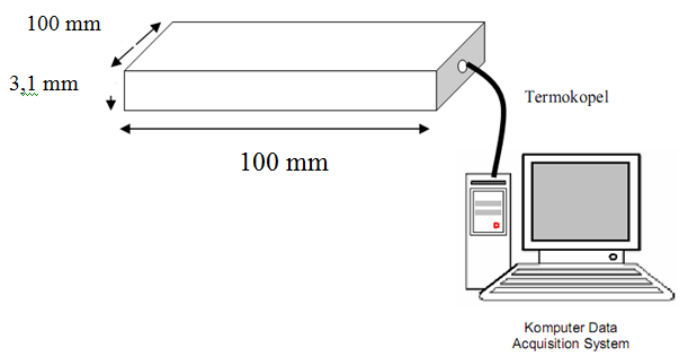

Gambar 1 : Contoh rangkaian pengujian warm rolling ${ }^{(7)}$

Penelitian ini diawali dengan pemanasan awal paduan $\mathrm{Cu}-\mathrm{Zn} 70 / 30$ dari suhu ruang ke suhu $700^{\circ} \mathrm{C}$ selama 30 menit lalu ditahan selama 90 menit untuk proses homogenisasi yang bertujuan untuk menghasilkan ukuran butir yang lebih seragam, kemudian dilanjutkan dengan pendinginan dalam oven ke suhu ruang (sekitar $25^{\circ} \mathrm{C}$ $50^{\circ} \mathrm{C}$ ) seperti yang terlihat pada Gambar 2 . Lalu, suhu dinaikkan ke suhu deformasi yaitu $300^{\circ} \mathrm{C}$ kemudian ditahan selama 120 menit sebelum dirol menggunakan mesin rol. Selanjutnya, sesudah paduan $\mathrm{Cu}-\mathrm{Zn}$ 70/30 mengalami pengerolan tahap kesatu dengan persentase reduksi masing-masing $25 \%$, 30\%, dan $35 \%$, maka material dipanaskan kembali sampai suhu $300^{\circ} \mathrm{C}$ lalu ditahan selama 120 menit, selanjutnya material dirol kembali dengan persentase reduksi masing-masing 25\%, 30\%, dan $35 \%$. Tahapan proses ditunjukkan pada Gambar 3.

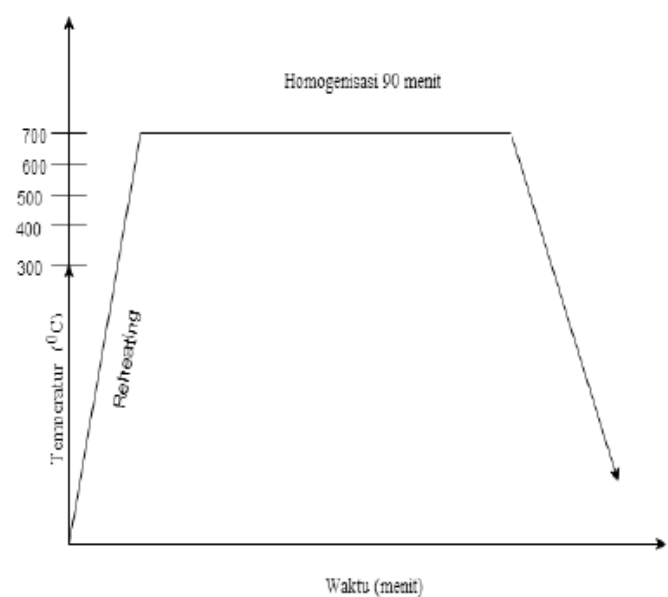

Gambar 2 : Diagram tahapan homogenisasi di suhu $700^{\circ} \mathrm{C}$ selama 90 menit

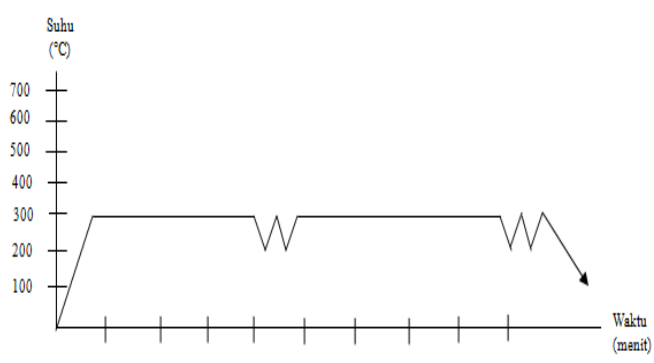

Gambar 3 : Diagram tahapan warm rolling pada suhu $300^{\circ} \mathrm{C}$ dengan metode double pass reversible dan persentase reduksi masing-masing $2 \times 25 \%$, 2×30\%, dan $2 \times 35 \%$

Proses warm rolling dilanjutkan dengan pengujian tarik. Tujuan dilakukannya pengujian tarik yaitu untuk mengetahui dan menentukan respon mekanis material dari suatu konstruksi, komponen, atau rakitan fabrikasi saat dikenakan beban atau deformasi tertentu yang mengalami peningkatan secara terus-menerus. Hasil pengujian tarik berupa kekuatan, ketangguhan, dan nilai keuletan karena perubahan degradasi material akibat pengujian tarik. Pengujian dan sampel uji tarik mengacu pada standar ASTM $E 8^{(9)}$. Output data yang dihasilkan adalah berupa perubahan panjang dan perubahan beban yang selanjutnya diolah ke dalam bentuk grafik tegangan-regangan.

Benda uji tarik dibuat searah pengerolan yaitu: $0^{\circ}$ dan mengacu pada standar ASTM E8 seperti yang terlihat pada Gambar 4. Selanjutnya dilakukan pengujian 
tarik menggunakan mesin uji tarik Servopulser.

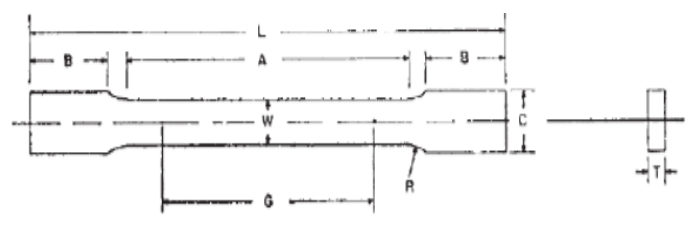

Gambar 4 : Sampel uji tarik dimana $L=$ minimal $100 \mathrm{~mm}, \mathrm{G}=25 \mathrm{~mm}, \mathrm{~W}=6 \mathrm{~mm}, \mathrm{R}=$ $6 \mathrm{~mm}, \mathrm{~A}=32 \mathrm{~mm}, \mathrm{~B}=30 \mathrm{~mm}$, dan $\mathrm{C}=10$ $\mathrm{mm}$

Untuk menghitung nilai UTS (ultimate tensile strength), YS (yield strength), dan $\varepsilon$ (elongasi) dari material paduan $\mathrm{Cu}-\mathrm{Zn}$ 70/30 menggunakan persamaan sebagai berikut :

$$
\sigma_{U T S}=F \max / A_{\circ}
$$

Lalu, setelah dilakukan pengujian tarik selanjutnya dilakukan pengamatan metalografi yang bertujuan untuk membandingkan struktur mikro paduan Cu-Zn 70/30 yang terjadi akibat proses warm rolling dengan variabel persentase (\%) reduksi. Dalam pengamatan metalografi menggunakan standar ASTM E3-01 ${ }^{(10)}$.

Setelah itu, dilakukan pengujian kekerasan untuk membandingkan hubungan antara peningkatan persentase (\%) reduksi warm rolling dengan tingkat keuletan material paduan $\mathrm{Cu}-\mathrm{Zn}$ 70/30. Metode pengujian kekerasan yang digunakan yaitu metode kekerasan Vickers dengan menggunakan standar ASTM E $92^{(11)}$ karena ketebalan material benda uji tipis yaitu $\leq 3,1$ $\mathrm{mm}$. Oleh karena itu, perlu dilakukan pengujian metode kekerasan mikro untuk mengetahui distribusi kekerasan baik di bagian tepi maupun di bagian tengah hasil warm rolling.

\section{HASIL DAN DISKUSI}

Dari hasil uji tarik diperoleh data seperti kekuatan tarik maksimum (UTS), perpanjangan hingga putus (\% Elongasi), dan kekuatan luluh $(\mathrm{YS})^{(12)}$ dari paduan $\mathrm{Cu}$ -
Zn 70/30 yang seperti ditunjukkan pada Tabel 2.

Tabel 2. Data hasil uji tarik paduan $\mathrm{Cu}-\mathrm{Zn}$ 70/30 setelah diproses warm rolling

\begin{tabular}{|c|c|c|c|}
\hline $\begin{array}{c}\text { Reduksi } \\
(\%)\end{array}$ & $\begin{array}{c}\text { UTS } \\
\text { (MPa) }\end{array}$ & $\begin{array}{c}\text { YS[11] } \\
\text { (MPa) }\end{array}$ & $\boldsymbol{\varepsilon}$ (\%) \\
\hline 0 & 358,5 & 188,9 & 60 \\
\hline 31,61 & 501,1 & 441,8 & 12,4 \\
\hline 41,93 & 599,3 & 466,1 & 8,2 \\
\hline 48,39 & 546,5 & 458,6 & 11,2 \\
\hline
\end{tabular}

Gambar 5 menunjukkan grafik hubungan antara \% reduksi warm rolling dan kekuatan tarik maksimum (ultimate tensile strength). Sedangkan gambar 6 menunjukkan hubungan antara \% reduksi warm rolling dan kekuatan tarik luluh YS (yield strength).

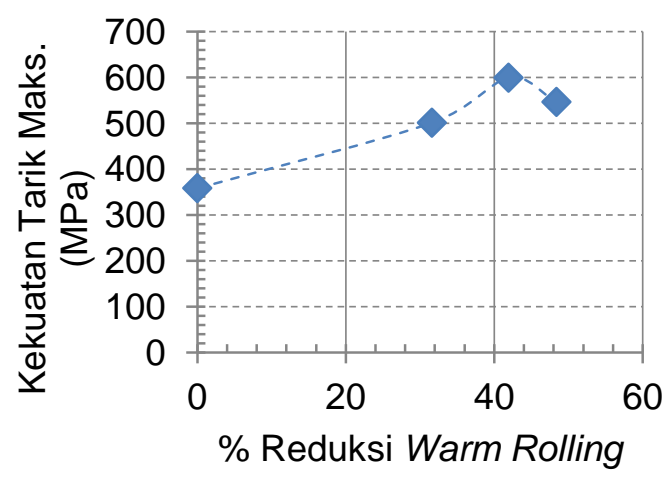

Gambar 5 : Hubungan \% reduksi warm rolling dan nilai kekuatan tarik maksimum (MPa)

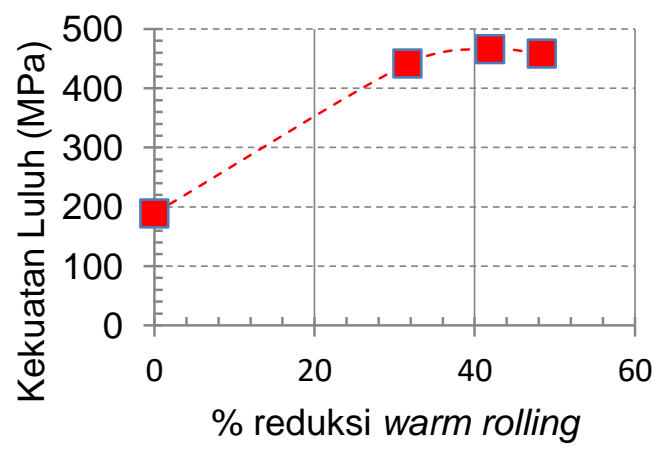

Gambar 6 : Hubungan \% reduksi warm rolling dan nilai kekuatan luluh ( $\mathrm{MPa})$

Sementara gambar 7 menunjukkan grafik hubungan antara \% reduksi warm rolling dan persenta-se elongasi. Untuk pa- 
duan $\mathrm{Cu}-\mathrm{Zn}$ 70/30 sebelum proses warm rolling (sete-lah proses homogenisasi pada suhu $700^{\circ} \mathrm{C}$ selama 90 menit) memiliki kekuatan tarik maksimum (UTS) $358,5 \mathrm{MPa}$; kekuatan luluh (YS) 188,9 MPa; dan \% elongasi $60 \%$.

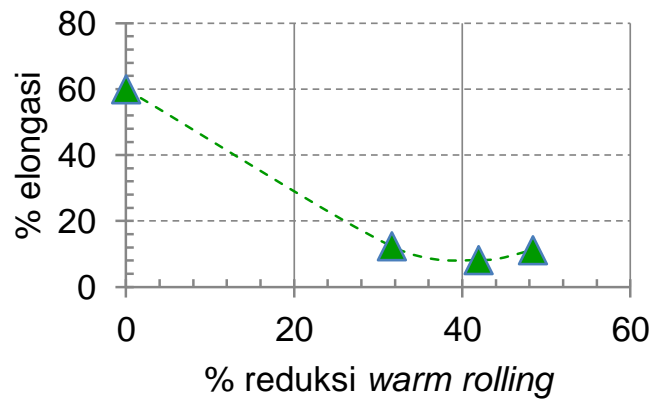

Gambar 7 : Hubungan \% reduksi warm rolling dan \% elongasi

Pada Gambar 5 menunjukkan hubungan antara \% reduksi warm rolling dan kekuatan tarik maksimum (MPa) yaitu kekuatan tarik maksimum meningkat dari $358 \mathrm{MPa}$ menjadi $599 \mathrm{MPa}$ ketika \% reduksi warm rolling mencapai $41,93 \%$ lalu menurun menjadi $546 \mathrm{MPa}$ pada reduksi $48,39 \%$. Sementara pada Gambar 6 menunjukkan hubungan antara \% reduksi warm rolling dan kekuatan luluh (MPa) yaitu kekuatan luluh meningkat dari $188 \mathrm{MPa}$ menjadi 466 $\mathrm{MPa}$ ketika reduksi $41,93 \%$ lalu menurun menjadi $458 \mathrm{MPa}$ di reduksi $48,39 \%$. Sedangkan, Gambar 7 menunjukkan hubungan antara \% reduksi warm rolling dan \% elongasi yaitu elongasi menurun menjadi $8,2 \%$ ketika reduksi $41,93 \%$ lalu elongasi meningkat menjadi $11,2 \%$ di reduksi $48,39 \%$.

Sementara itu, untuk hasil uji kekerasan pada paduan $\mathrm{Cu}-\mathrm{Zn}$ 70/30 ditunjukkan pada Tabel 3.

Tabel 3. Data hasil uji kekerasan paduan Cu-Zn 70/30 setelah diproses warm rolling

\begin{tabular}{|c|c|}
\hline $\begin{array}{c}\text { Reduksi } \\
(\%)\end{array}$ & $\begin{array}{c}\text { Rata-rata } \\
\text { Kekerasan (HV) }\end{array}$ \\
\hline 0 & 60 \\
\hline 31,61 & 154 \\
\hline 41,93 & 162 \\
\hline 48,39 & 160 \\
\hline
\end{tabular}

Gambar 8 menunjukkan grafik hubungan antara \% reduksi warm rolling dan nilai kekerasan Vickers $(\mathrm{HV})$ yaitu nilai kekerasan paduan $\mathrm{Cu}-\mathrm{Zn}$ 70/30 meningkat hingga 162 HV ketika reduksi $41,93 \%$ lalu menurun menjadi 160 HV di reduksi 48,39\%.

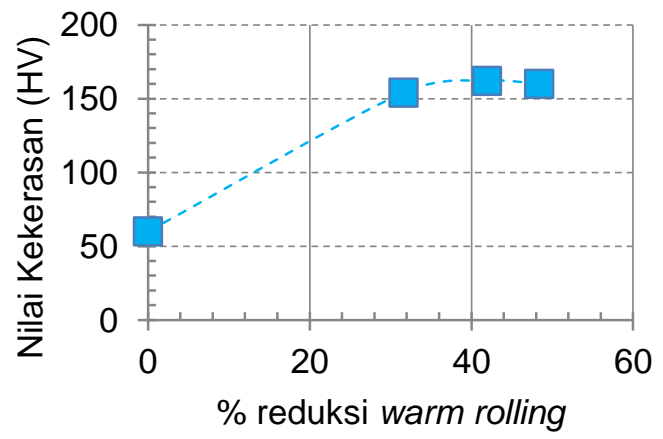

Gambar 8 : Hubungan antara \% reduksi warm rolling dan nilai kekerasan (HV)

Penurunan nilai kekerasan (HV) dan nilai kekuatan tarik baik kekuatan tarik maksimum (UTS) maupun kekuatan luluh (YS) serta peningkatan nilai elongasi (\%) ketika reduksi $48,39 \%$ disebabkan karena adanya rekristalisasi parsial dengan kehadiran butir-butir berukuran mikro seperti yang terlihat pada Gambar 9.

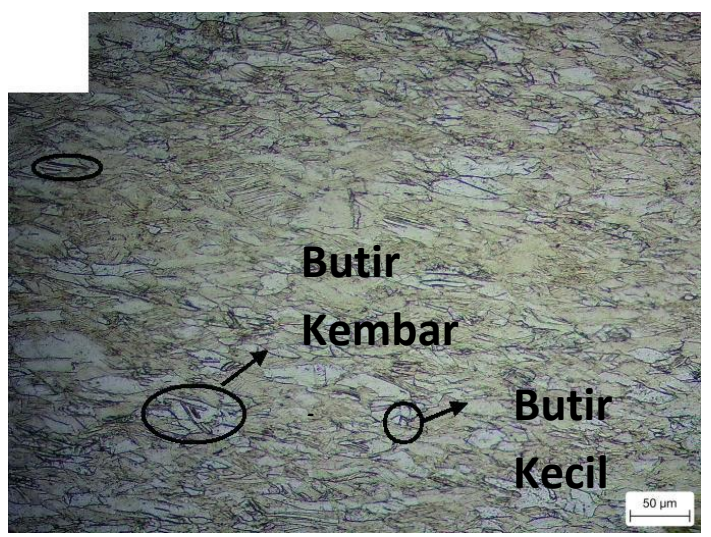

Gambar 9 : Foto struktur mikro paduan $\mathrm{Cu}$ Zn 70/30 yang dilakukan deformasi warm rolling pada reduksi $48,39 \%$

Menurut penelitian yang dilakukan oleh LJ. Radovic ${ }^{(13)}$ yang mempelajari tentang perilaku rekristalisasi hasil perlakuan termomekanik yang berbeda terhadap paduan $\mathrm{Al}-4,5 \mathrm{Mg}-0,5 \mathrm{Cu}$. Perlakuan dilakukan dalam dua tahapan anil yaitu pertama pada suhu $565^{\circ} \mathrm{C}$ selama 6 jam dan kedua pada suhu $450^{\circ} \mathrm{C}$ selama 4 jam 
dan bertujuan untuk mengendalikan pengendapan partikel antar logam $\mathrm{Cu}-\mathrm{Mg}$, lalu paduan $\mathrm{Al}-4,5 \mathrm{Mg}-0,5 \mathrm{Cu}$ dicanai dingin dengan reduksi $20 \%$, $40 \%$, dan $60 \%$, serta pada akhirnya dilakukan pelunakan selama 3 jam pada suhu $250^{\circ} \mathrm{C}, 280^{\circ} \mathrm{C}$, dan $350^{\circ} \mathrm{C}$, dengan kecepatan pemanasan lambat $0,6^{\circ} \mathrm{C} /$ menit dan kecepatan pemanasan cepat $25^{\circ} \mathrm{C} /$ menit.

Paduan $\mathrm{Al}-4,5 \mathrm{Mg}-0,5 \mathrm{Cu}$ yang dianil pada suhu $250^{\circ} \mathrm{C} / 3$ jam dengan kecepatan pemanasan cepat mengalami peningkatan nilai kekerasan sebanding dengan meningkatnya \% reduksi sementara pada kecepatan pemanasan lambat terjadi penurunan nilai kekerasan pada reduksi $40 \%$. Lalu paduan $\mathrm{Al}-4,5 \mathrm{Mg}-0,5 \mathrm{Cu}$ yang dianil pada suhu $280^{\circ} \mathrm{C} / 3$ jam mengalami penurunan kekerasan ketika \% reduksi meningkat. Sementara pada paduan Al-4,5 $\mathrm{Mg}-0,5 \mathrm{Cu}$ yang dianil pada suhu $350^{\circ} \mathrm{C}$ maka kekerasan menurun berbanding terbalik dengan peningkatan $\%$ reduksi.

Penurunan kekerasan yang terjadi pada paduan Al-4,5 $\mathrm{Mg}-0,5 \mathrm{Cu}$ yang dilakukani anil pada suhu $280^{\circ} \mathrm{C} / 3$ jam dan $350^{\circ} \mathrm{C} / 3$ jam mengindikasikan adanya butirbutir rekristalisasi baru yang muncul. Perubahan mikrostruktur setelah canai dingin dan anil berhubungan erat dengan peningkatan \% reduksi canai dan suhu anil yang menyebabkan terjadinya rekristalisasi yang menghasilkan struktur butir partial recrystallized dan fully recrystallized. Oleh karena itu, penurunan nilai kekerasan pada reduksi tertinggi yaitu sebesar 48,9\% disebabkan karena adanya rekristalisasi parsial yang dibuktikan dengan kehadiran butir (nuclei) seperti yang terlihat pada Gambar 9.

Selain itu, berdasarkan penelitian yang dilakukan oleh N.K Tewary ${ }^{(14)}$, yang mempelajari tentang perlakuan termomekanik terhadap High Manganese TWIP steel. Perlakuan termomekanik dilakukan dengan memberikan canai dingin dengan reduksi sebesar $10 \%$ dan 30\%. Dari penelitian tersebut didapatkan nilai Yield strength dan Ultimate tensile strength yang meningkat sebanding dengan meningkatnya \% reduksi. Sampel uji yang dianil sampai suhu 600$900^{\circ} \mathrm{C}$ selama 5 menit menghasilkan penurunan nilai Yield Strength dan Ultimate
Tensile Strength dibandingkan dengan sampel uji tanpa dianil. Penurunan Yield Strength dan Tensile Strength ini disebabkan adanya evolusi struktur mikro akibat adanya rekristalisasi parsial.

Kehadiran butir baru hasil rekristalisasi parsial merupakan akibat dari jumlah densitas dislokasi yang tinggi selama canai dingin sehingga menghasilkan dynamic recovery yang terbatas pada TWIP steel ${ }^{(15)}$. Butir hasil rekristalisasi parsial yang berukuran submicron menyebabkan material lebih ulet. Oleh karena itu, adanya penurunan kedua kekuatan tarik baik ultimate tensile strength maupun yield strength disebabkan karena rekristalisasi parsial yang dibuktikan dengan kehadiran butir (nuclei) sepertiyang terlihat pada Gambar 9.

\section{KESIMPULAN}

Nilai kekuatan tarik (UTS dan YS) hasil warm rolling di suhu $300^{\circ}$ semakin tinggi sebanding dengan peningkatan \% reduksi warm rolling yaitu masing-masing untuk nilai UTS sebesar 501,1 MPa; 599,3 $\mathrm{MPa}$; lalu menurun menjadi 546,5 MPa serta untuk nilai kekuatan luluh sebesar 441,8 $\mathrm{MPa} ; 466,1 \mathrm{MPa}$; lalu menurun menjadi 458,6 MPa. Selain itu, nilai kekerasan meningkat sebanding dengan peningkatan $\%$ reduksi warm rolling yaitu sebesar 154 HV; $162 \mathrm{HV}$; lalu menurun menjadi $160 \mathrm{HV}$. Sedangkan persentase elongasi semakin menurun berbanding terbalik dengan peningkatan \% reduksi masing-masing sebesar $12,4 \%$; $8,2 \%$; lalu meningkat menjadi $11,2 \%$.

Pada proses warm rolling di suhu $300^{\circ} \mathrm{C}$ dengan waktu tahan anil 120 menit, sifat mekanik seperti kekerasan dan kekuatan tarik baik ultimate tensile strength maupun yield strength serta kekerasan semakin meningkat sebanding dengan penambahan \% reduksi. Namun, ketika \% reduksi mencapai $48,39 \%$ sifat mekaniknya menurun. Hal tersebut disebabkan karena terjadi fenomena rekristalisasi parsial. Fenomena rekristalisasi parsial pada reduksi warm rolling sebesar $48,39 \%$ dibuktikan dengan kehadiran butir kecil (nuclei) berukuran mikron.

Selain itu, proses warm rolling pada suhu $300^{\circ} \mathrm{C}$ menghasilkan kekerasan dan kekuatan tarik tertinggi pada reduksi $41,93 \%$ 
yaitu masing-masing sebesar 162 HV; UTS 599,3 MPa; dan YS 466,1 MPa. Namun, \% elongasi pada reduksi $41,93 \%$ nilainya terkecil yaitu sebesar $8,2 \%$

\section{DAFTAR PUSTAKA}

1. William D.Callister Jr., An Introduction : Material Science and Engineering, John Wiley \& Son, Inc., 2007, hal.373

2. Nestorovic, S. and Tancic, D., "Anneal Strengthening Effect in Sintered Copper-Based Alloys". International Conference on Deformation and Fracture in Structural PM Materials, Slovaki,. (2002), hal.144 - 15

3. Kouzeli, M. and Mortensen, A., "Size Dependent Strengthening in Practice Reinforced Aluminum", Acta Metallurgical., 50 (2002), hal.39-51.

4. Majta, J., Stefanska-Kqdziela, M. and Muszka, K., "Modeling of Strain Rate Effects on Microstructure Evolution and Mechanical Properties of HSLA and IF$\mathrm{Ti}$ Steels", The 5th International Conference on HSLA Steels, 8 - 10 November, 2005. Sanya, Hainan, China, (2005) hal. $513-517$.

5. Hust, J.G. and Lankford, A.B., "Thermal Conductivity of Aluminum, Copper, Iron and Tungsten for Suhues from $1 \mathrm{~K}$ to the Melting Point", National Bureau of Standards: Boulder, CO. NBSIR 843007, (1984)

6. Nestorovic, S., "Influence of Deformation Degree at Cold-Rolling on the Anneal Hardening Effect in Sintered Copper-Based Alloys", Journal of Mining and Metallurgy, vol. 40, issue 1, (2004), hal. $101-10$

7. Eka Febriyanti, Pengaruh Suhu Warm rolling dan Derajat Deformasi terhadap Sifat Mekanis dan Morfologi Struktur Paduan Cu-Zn 70/30, Tesis, (2015)

8. Nestrovic, S., "Influence of Time Annealing on Anneal Hardening Effect of A Cast Cu-Zn Alloy", Journal of
Mining and Metallurgy, vol. 39, issue (34)B, (2003), hal.489-497

9. ASTM E8, 2003, "Standard Test Methods for Tension Testing of Metallic Materials"

10. ASTM E3-01, 2003, "Standard Guide for Preparation for Metallographic Specimens"

11. ASTM E92, 2003, "Standard Test Methods for Vickers Hardness of Metallic Materials"

12. Krishna Chenna, S., et.al., "On the Prediction of Strength from Hardness for Copper Alloys", Journal of Materials, (2013), article ID 352578, Hindawi Publishing Corporation, hal.1-6

13. L.J Radovic et.al., "The Influence of Thermomechanical Treatment on Recrystallization of Al Mg4,5Cu0,5 Alloy", Metallurgija Journal of Metallurgy, Review Paper AMES, hal.83-88.

14. N.K Tewary, S.K Ghosh,and S. Chtterjee, "Effect of Annealing on Microstructure and Mechanical Behaviour of Cold Rolled Low C, High Mn TWIP Steel, International Journal of Metallurgical Engineering, (2015), vol. 4 , issue 1 , hal. 12-23

15. G. Dini, A. Najafizadeh, S. M. MonirVaghefi and R. Ueji, "Grain Size Effect on the Martensite Formation in a HighManganese TWIP Steel by the Rietveld Method", J. Mater. Sci. Technol, Vol. 26, (2010), hal. 181-186, 